Article

\title{
Brazing Ti-48Al-2Nb-2Cr Alloys with Cu-Based Amorphous Alloy Filler
}

\author{
Gang Wang ${ }^{1,2, *(\mathbb{D})}$, Peng Wu ${ }^{1}$, Wei Wang ${ }^{3}$, Dongdong Zhu ${ }^{4, *}$, Caiwang Tan ${ }^{5}$, Yongsheng Su ${ }^{1}$, \\ Xinying Shi ${ }^{2}$ (i) and Wei Cao ${ }^{2}$ (B) \\ 1 School of Mechanical and Automotive Engineering, Anhui Polytechnic University, Wuhu 241000, China; \\ ahpuwp@163.com (P.W.); sysh@ahpu.edu.cn (Y.S.) \\ 2 Nano and Molecular Systems Research Unit, University of Oulu, P.O. Box 3000, FIN-90014 Oulu, Finland; \\ xinying.shi@oulu.fi (X.S.); wei.cao@oulu.fi (W.C.) \\ 3 School of Mechanical Engineering, Anhui Machine and Electricity College, Wuhu 241002, China; \\ ahjdww@163.com \\ 4 School of Mechanical Engineering, Quzhou University, Quzhou 324000, China \\ 5 State Key Laboratory of Advanced Welding and Joining, Harbin Institute of Technology, Harbin 150001, \\ China; tancaiwang@163.com \\ * Correspondence: gangwang@ahpu.edu.cn (G.W.); zhudd8@163.com (D.Z.); Tel.: +86-553-2871252 (G.W.)
}

Received: 4 May 2018; Accepted: 30 May 2018; Published: 4 June 2018

Featured Application: The results of present work will provide the possibility for the preparation of TiAl alloy shaped parts and expand the application area of amorphous alloys.

\begin{abstract}
In this work, the Ti-48Al-2Nb-2Cr (at. \%) alloy was successfully brazed using a Cu-based amorphous filler in $600 \mathrm{~s}$ under varied brazing temperatures. The element diffusion, microstructure, and precipitation phase of the joints are analyzed in detail, and the formation schemes are discussed. Reaction products in the joints are found as $\mathrm{AlCuTi}, \mathrm{Ti}_{2} \mathrm{Al}, \alpha$ - Ti, and $(\mathrm{Ti}, \mathrm{Zr})_{2}(\mathrm{Cu}, \mathrm{Ni})$. The interfacial microstructures varied subjected to the brazing temperature, while the shear strength of the joint firstly increased, and then accordingly decreased. The maximum shear strength of $266 \mathrm{MPa}$ was reached under a brazing temperature of $1213 \mathrm{~K}$ and a holding time of $600 \mathrm{~s}$. A formation mechanism was proposed to explain the shear strength variation following the width and amount of brittle compounds in the interfacial reaction layer.
\end{abstract}

Keywords: Ti-48Al-2Nb-2Cr alloy; amorphous alloy filler; brazing; microstructure; shear strength

\section{Introduction}

Due to their low density, high specific strength, excellent creep strength, and good oxidation resistance at elevated temperature, the TiAl alloys are considered ideal materials for high-temperature applications in aerospace vehicles, automotive engines, and airframes. However, the practical application of TiAl alloys is mainly limited by their intrinsic brittleness and poor workability, which makes it very difficult to prepare complicated and large components [1-4]. In order to expand the applications of TiAl alloys, it is necessary to join individual and small components into complex and large components.

So far, several techniques, such as fusion welding [5-7], diffusion bonding [8-10], and brazing [11-13], have been applied to join TiAl alloys. Despite their partial successes, these techniques are not practical in large-scale applications. For instance, the fusion welding of TiAl alloys suffers from stringent conditions such as preheating and postheating, and inevitable solidification crack. As for diffusion bonding, a long-time exposure of TiAl alloys at high bonding temperature and high pressure can 
change their microstructure. Alternatively, vacuum brazing is widely used to braze TiAl alloys with good joint mechanical properties. Such a method is facile and economical, and can be performed at low temperatures. So far, several kinds of filler metals have been employed for brazing TiAl alloys, such as Ag-based [14,15], Al-based [16], and Ti-based eutectic braze alloys [17-19]. Although Ag-based and Al-based filler metals have low liquidus temperature and excellent wettability, the formed joints have low joining strength and working temperature, which severely limit their practical applications. High joining strength can be realized via Ti-based fillers due to their good compatibility with TiAl alloys. Song et al. [19] brazed TiAl alloy using TiNi eutectic alloy, and the maximum room temperature shear strength reached up to $196 \mathrm{MPa}$. However, the high melting point of the TiNi eutectic braze alloy demands a rather high brazing temperature of more than $1453 \mathrm{~K}$. Lee et al. [11] brazed TiAl intermetallics with Ti-Cu-Ni filler metal, which has a liquidus temperature of $1233 \mathrm{~K}$. The obtained excellent bonding strength was achieved with a brazing temperature of $1473 \mathrm{~K}$, which was higher than the liquidus temperature.

Recently, some Ti-based amorphous filler metals have been developed for brazing TiAl alloys, owing to their advantage of superior wettability, accelerated atomic diffusion, enhanced surface reaction, etc. This advantage is ascribed to the instantaneous melting and homogeneous features of these amorphous fillers. In addition, adding $\mathrm{Zr}$ into the Ti-based alloy filler can effectively decrease the brazing temperature and reduce the residual stress developed in the joint, causing an enhanced joint strength [20-22]. Li et al. studied the weldability of Ti-48Al-2Nb-2Cr (at. \%) alloys by TiZrCuNiCo amorphous ribbon, and the maximum tensile strength at room temperature reached $316 \mathrm{MPa}$ [23]. Wang et al. brazed TiAl and TC4 alloys with $\mathrm{TiZrCuNi}(\mathrm{Mo})$ and obtained the maximum shear strengths of $351 \mathrm{MPa}$ and $437 \mathrm{MPa}$ with the Mo-free and $8 \mathrm{wt} \%$ Mo filler metals, respectively [24]. Cai et al. reported that the Ti-45Al-2Mn-2Nb-1B (at. \%) alloys were joined using amorphous Ti-37.5Zr-15Cu-15Ni (wt \%) ribbon, and a tensile strength of $468 \mathrm{MPa}$ was obtained. The results shown that the mechanical behavior of joints is highly dependent on the feature of the interface, especially the content of $(\mathrm{Ti}, \mathrm{Zr})_{2}(\mathrm{Cu}, \mathrm{Ni})[25]$. From the above analysis, it can be concluded that the Ti-based and Ag-based filler alloys are useful for achieving the sound joint of TiAl alloys. It is worth noting that the Cu-based filler owns a lower brazing temperature than the Ti-based counterpart. Therefore, the cheaper copper filler may bring in unique mechanical properties along with its facile brazing requirements.

In this paper, a novel low temperature Cu-based amorphous alloy foil was designed based on the binary deep eutectic method [26]; it was prepared by rapid solidification, and then used to braze Ti-48Al-2Nb-2Cr alloys. The interface microstructure was investigated, the mechanical properties of the joint were tested at room temperature, and the interfacial reactions were discussed in detail.

\section{Materials and Methods}

\subsection{Materials}

TiAl alloy with a nominal composition of Ti-48Al-2Nb-2Cr (at. \%) was prepared by arc melting with high purity $\mathrm{Ti}, \mathrm{Al}$, and $\mathrm{Cr}$ metals, and an $\mathrm{Nb}-\mathrm{Al}$ intermediate alloy. To ensure a compositional homogeneity, the alloy ingots were re-melted at least four times, and the electromagnetic stirring system was introduced to the equipment by adding a current loop under the water-cooled copper plate. Subsequently, the as-cast alloy was treated at $1653 \mathrm{~K}$ for $1800 \mathrm{~s}$ in Ar atmosphere to eliminate the residual stress and shrinkage porosity. The composition of the amorphous foils is $\mathrm{Cu}_{41.83} \mathrm{Ti}_{30.21} \mathrm{Zr}_{19.76} \mathrm{Ni}_{8.19}$ (at. \%), which were prepared by re-melting the alloy ingot in quartz tubes and ejecting through a nozzle onto a copper wheel rotating at a velocity of $40 \mathrm{~m} / \mathrm{s}$ in a purified argon atmosphere. The thickness of the foil was about $30 \mu \mathrm{m}$. The solidus and liquidus temperature of the foil were $1103 \mathrm{~K}$ and $1143 \mathrm{~K}$, respectively [27]. The amorphous structure of the brazing foil was examined by an X-ray diffraction (XRD, D8, Bruker, Germany) using $\mathrm{Cu} K \alpha$ radiation. 


\subsection{Brazing}

The size of the TiAl sample for brazing was $4 \mathrm{~mm} \times 4 \mathrm{~mm} \times 4 \mathrm{~mm}$ and $10 \mathrm{~mm} \times 10 \mathrm{~mm} \times 4 \mathrm{~mm}$. Before joining, the surfaces of the samples were ground by 1000 grit silicon carbide paper and cleaned ultrasonically for $600 \mathrm{~s}$. The Cu-based filler was placed between the Ti-48Al-2Nb-2Cr base materials to form a sandwich type, as shown in Figure 1a. The brazing experiments were done by JVLF211 vacuum brazing equipment. The accuracy of temperature controlling was $\pm 1 \mathrm{~K}$. The brazing temperature was from $1183 \mathrm{~K}$ to $1273 \mathrm{~K}$, and the brazing time was set as $600 \mathrm{~s}$. The brazing process was conducted in a vacuum of $1 \times 10^{-3} \mathrm{~Pa}$. At the beginning, the brazing sample was heated up to $573 \mathrm{~K}$ at a rate of $0.167 \mathrm{~K} / \mathrm{s}$ and held steady for $1200 \mathrm{~s}$ to make the organic glue volatilize and keep the brazing surfaces clean. Then, the temperature was increased to the target brazing temperature at a heating rate of $0.167 \mathrm{~K} / \mathrm{s}$, and kept constant for $600 \mathrm{~s}$. Finally, the brazed samples were cooled down at a rate of $0.083 \mathrm{~K} / \mathrm{s}$ to $573 \mathrm{~K}$, and then cooled in the furnace.

After joining, the microstructure and composition of the joints were examined by scanning electron microscopy (SEM, SU8010, Hitachi, Tokyo, Japan) with an energy-dispersive X-ray spectrometer (EDS) and X-ray diffraction. The structural analysis of the fractured surface of the joint was tested by XRD. Shear testing was performed by a universal testing machine Instron 5500 to evaluate the strength of the brazed joint. A schematic diagram of the shear test is shown in Figure 1b. The average shear strength of each brazing condition was determined from three brazed samples.

a)

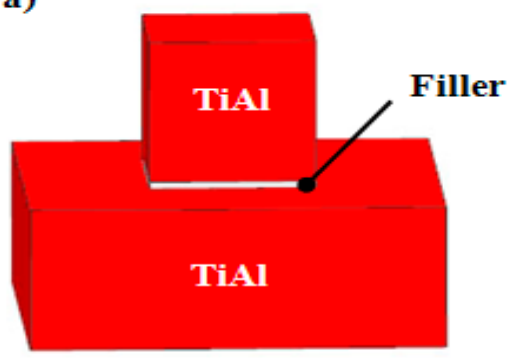

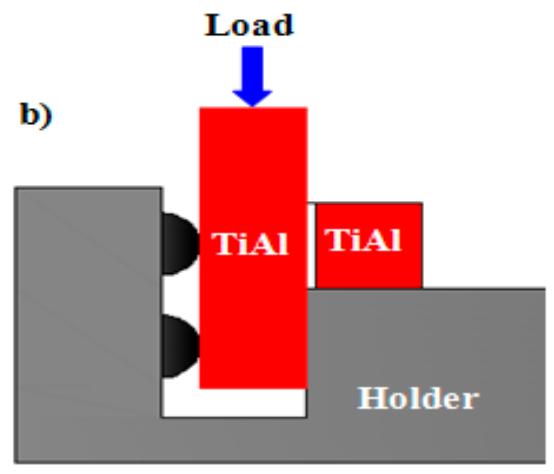

Figure 1. Schematic diagram of (a) assembling brazing and (b) shear test experiment.

\section{Results and Discussion}

\subsection{Microstructure of Ti-48Al-2Nb-2Cr Alloy}

Figure 2 shows the SEM image and XRD pattern of the as-cast Ti-48Al-2Nb-2Cr alloy. The Ti-48Al-2Nb-2Cr alloy primarily consists of a lamellar structure, gray phases, and a few white phases. The chemical composition of the typical phases of the as-cast Ti-48Al-2Nb-2Cr alloy is listed in Table 1. According to the EDS and XRD results, gray areas are identified as the $\gamma$ phase due to high Al content. The lamellar structure is $\alpha_{2}+\gamma$ phase. During the cooling process, the liquid through peritectic reaction $L+\beta \rightarrow \alpha$ has transformed to the $\alpha$ phase incompletely, so that the retained $\beta$ phase exists in a lamellar microstructure [28]. The white phases are rich in $\mathrm{Cr}$ and poor in $\mathrm{Al}$, as shown in Table 1 . Thus, the white phase should be the $\mathrm{B}_{2}$ phase produced by the transformation of the retained $\beta$ phase. The similar results of the TiAl alloy have been demonstrated in the previous work $[29,30]$. 

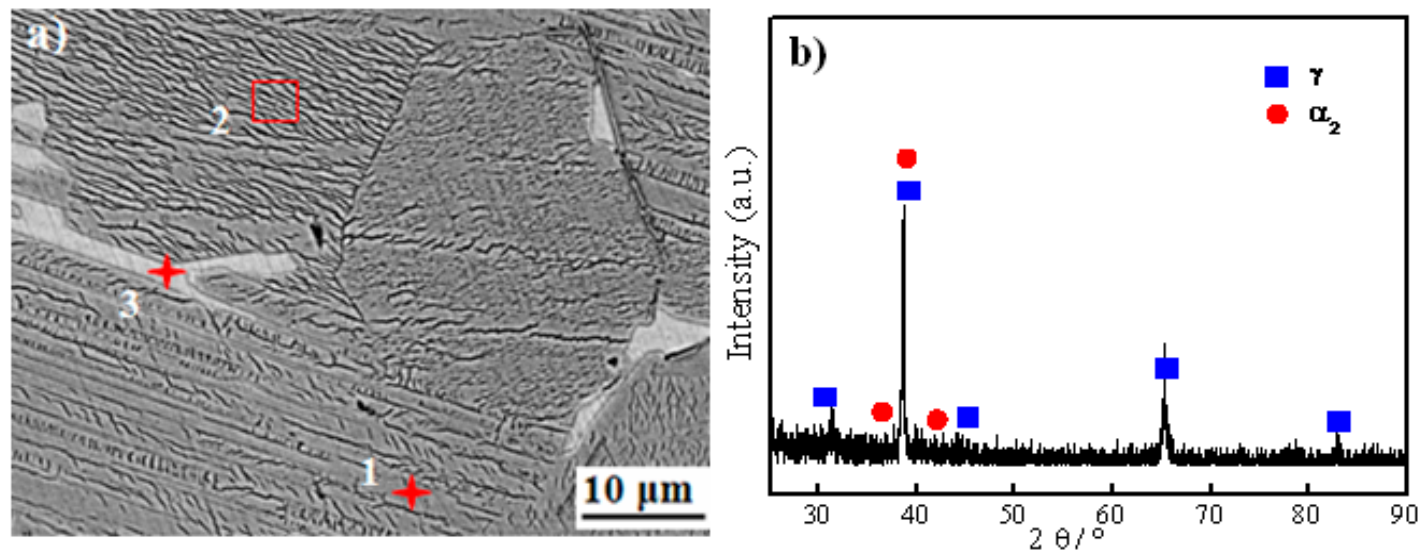

Figure 2. (a) Scanning electron microscopy (SEM) image and (b) X-ray diffraction (XRD) pattern of Ti-48Al-2Nb-2Cr base material.

Table 1. Chemical composition and possible phase of each spot marked in Figure 1 (at. \%).

\begin{tabular}{cccccc}
\hline Position & Ti & Al & Nb & Cr & Possible Phase \\
\hline 1 & 49.96 & 44.83 & 1.70 & 3.52 & $\gamma$ \\
2 & 48.12 & 47.60 & 1.06 & 3.22 & $\gamma+\alpha_{2}$ \\
3 & 54.11 & 33.09 & 1.21 & 11.59 & $\mathrm{~B}_{2}$ \\
\hline
\end{tabular}

\subsection{Interfical Microstructure of the Brazed Joint}

Figure 3 shows the interfacial microstructures and corresponding EDS results for the joint brazed at $1213 \mathrm{~K}$ for $600 \mathrm{~s}$. Clearly, the TiAl substrates are tightly bonded by the Cu-based amorphous filler. No cracks or pores are found in the joint. Obvious reaction layers are detected in the interface, as shown in Figure 3a, which can be attributed to the interdiffusion and nucleation of new phases at the brazing temperature or during cooling. From Figure $3 \mathrm{~b}-\mathrm{e}$, the main elements of $\mathrm{Ti}, \mathrm{Cu}, \mathrm{Zr}$, and $\mathrm{Ni}$ are widely distributed in the whole joint. Moreover, Ti is aggregated on the location of the blocky black phase with the absence of $\mathrm{Cu}$ and $\mathrm{Zr}$. It can be seen that the $\mathrm{Al}$ mainly distributes in the Ti-48Al-2Nb-2Cr side of the seam, as shown in Figure 3f. From Figure 3g,h, the existence of $\mathrm{Nb}$ and $\mathrm{Cr}$ in the brazing beam is attributed to the dissolution and diffusion of elements from the Ti-48Al-2Nb-2Cr alloy into the filler metal during brazing.

Figure 4a shows detailed microstructures of the brazed joint at $1123 \mathrm{~K}$ for $600 \mathrm{~s}$. The width of the brazed joint is about $90 \mu \mathrm{m}$, which is thicker than the amorphous filler. Two kinds of reaction zones were identified in the brazed joint, which are marked as zone I and II, respectively. Figure $4 \mathrm{~b}, \mathrm{c}$ demonstrates the high magnification images of these two characteristic zones. Based on the contrast differences, zone I mainly consists of two phases marked by A and B. Some $\mathrm{B}_{2}$ phase can be observed in the TiAl alloy side. Similarly, zone II is also a two-phase mixed region, as marked by C and D. Table 1 lists the chemical composition of the brazed joints through EDS. From Figure 4b, a lamellar structure approximately $10-\mu \mathrm{m}$ thick composed of alternate black and grey strips are detected in the brazed joint adjacent to the TiAl base material. According to the EDS results, the black phase (spot A) is mainly composed of $\mathrm{Ti}$ and $\mathrm{Al}$ at an approximate ratio of 2:1 with few $\mathrm{Zr}, \mathrm{Cu}, \mathrm{Ni}, \mathrm{Nb}$, and $\mathrm{Cr}$. Based on the composition of the selected spots (marked as A-D in Figure $4 b, c$ ) and previous studies [31], spot $\mathrm{A}$ is inferred as the $\mathrm{Ti}_{2} \mathrm{Al}$. It is reported that $\mathrm{Ti}_{2} \mathrm{Al}$ was an intermediate phase during the phase transformation between the $\mathrm{Ti}_{3} \mathrm{Al}$ and $\mathrm{TiAl}$ phases, and it was hexagonal with lattice parameters $\mathrm{a}=0.29 \mathrm{~nm}$ and $\mathrm{c}=1.39 \mathrm{~nm}[32,33]$. Furthermore, Xiong et al. demonstrated that there was a reaction of $\mathrm{Ti}+\mathrm{TiAl} \rightarrow \mathrm{Ti}_{2} \mathrm{Al}$ during hot press sintering [34]. Similarly, the gray phase (spot $\mathrm{B}$ ) is mainly composed of $\mathrm{Al}, \mathrm{Cu}$, and Ti at a ratio of 1:1:1. Based on the composition, spot $\mathrm{B}$ is inferred to be AlCuTi. As Shiue reported, this kind of intermetallic was common in the reactions between TiAl alloy, $\mathrm{Cu}$, and 
$\mathrm{Ni}$ in the brazing process [35]. According to the Al-Cu-Ti ternary alloy phase diagram [14], AlCuTi and TiAl share a boundary curve, indicating that AlCuTi is likely to be directly adjacent to the TiAl phase of the base material, which is consistent with our experimental observation, as shown in Figure 4b. Thus, spot $\mathrm{B}$ is identified as AlCuTi corresponding to the Al-Cu-Ti ternary alloy phase diagram. Also, the formation of a $\mathrm{AlCuTi}$ intermetallic compound in brazed joints has been reported in previous works. Liu et al. reported the presence of a AlCuTi phase in transparent alumina ceramic and TiAl alloy with AgCuTi filler metal [14]. Shiue et al. observed the obvious AlCuTi layer through SEM at the interface between BAg- 8 and TiAl substrate for the specimen brazed at $1223 \mathrm{~K}$ [34]. Spot C in Figure 4c was mainly composed of 76.94 at. \% $\mathrm{Ti}$ and 6.83 at. \% Al. It has been reported that $\mathrm{Al}$ is $\alpha$-Ti stabilizer, while $\mathrm{Cu}$ and $\mathrm{Ni}$ are $\beta$-Ti stabilizer elements [36]. Therefore, spot $\mathrm{C}$ was inferred to be $\alpha$-Ti. Spot D in zone II was mainly composed of $\mathrm{Zr}, \mathrm{Ti}, \mathrm{Cu}$, and $\mathrm{Ni}$. The atom ratio of $\mathrm{Cu}+\mathrm{Ni}$ and $\mathrm{Ti}+\mathrm{Zr}$ was approximately 1:2. Compared with the original contents of $\mathrm{Cu}$ in an amorphous alloy, the decrease of $\mathrm{Cu}$ contents mainly caused by the consumption of copper from molten braze during brazing results in the formation of $\mathrm{AlCuTi}$, as aforementioned. Both $\mathrm{Cu}$ and $\mathrm{Ni}$ are completely miscible with each other, as well as $\mathrm{Ti}$ and $\mathrm{Zr}$. $\mathrm{Cu}$ and $\mathrm{Ni}$ have a strong affinity to $\mathrm{Ti}(\mathrm{Zr})$, and they are apt to form $(\mathrm{Ti}, \mathrm{Zr})_{2}(\mathrm{Cu}, \mathrm{Ni})$. In fact, both element pairs of $\mathrm{Ti}$ and $\mathrm{Zr}$, and $\mathrm{Cu}$ and $\mathrm{Ni}$, are not only chemically compatible with each other, they are also fully soluble to each other. Therefore, $\mathrm{Zr}$ and $\mathrm{Ni}$ can be regarded namely as $\mathrm{Ti}$ and $\mathrm{Cu}$ in the intermetallics herein. Thus, the $\mathrm{Zr}_{2} \mathrm{Cu}$ and $\mathrm{Zr}_{2} \mathrm{Ni}$ can be regarded as $\mathrm{Ti}_{2} \mathrm{Cu}$ and $\mathrm{Ti}_{2} \mathrm{Ni}$. Therefore, the four phases can be collectively referred to as $(\mathrm{Ti}, \mathrm{Zr})_{2}(\mathrm{Cu}, \mathrm{Ni})$. So, spot $\mathrm{D}$ can be considered as having a phase formula of $(\mathrm{Ti}, \mathrm{Zr})_{2}(\mathrm{Cu}, \mathrm{Ni})$. The formation of $(\mathrm{Ti}, \mathrm{Zr})_{2}(\mathrm{Cu}, \mathrm{Ni})$ phase was also demonstrated in the previous work when amorphous filler metal was used $[37,38]$. Figure 5 shows the XRD patterns of the fractured surface of the sample brazed at $1213 \mathrm{~K}$ for $600 \mathrm{~s}$. However, AlCuTi has not been detected by XRD due to the amount being too small for detection by the equipment. Based on the micro-XRD results, the chemical composition in Table 2, and the phase diagrams, phases $\mathrm{A}, \mathrm{B}, \mathrm{C}$, and $\mathrm{D}$ can be recognized as $\mathrm{Ti}_{2} \mathrm{Al}, \mathrm{AlCuTi}, \alpha-\mathrm{Ti}$, and $(\mathrm{Ti}, \mathrm{Zr})_{2}(\mathrm{Cu}, \mathrm{Ni})$.

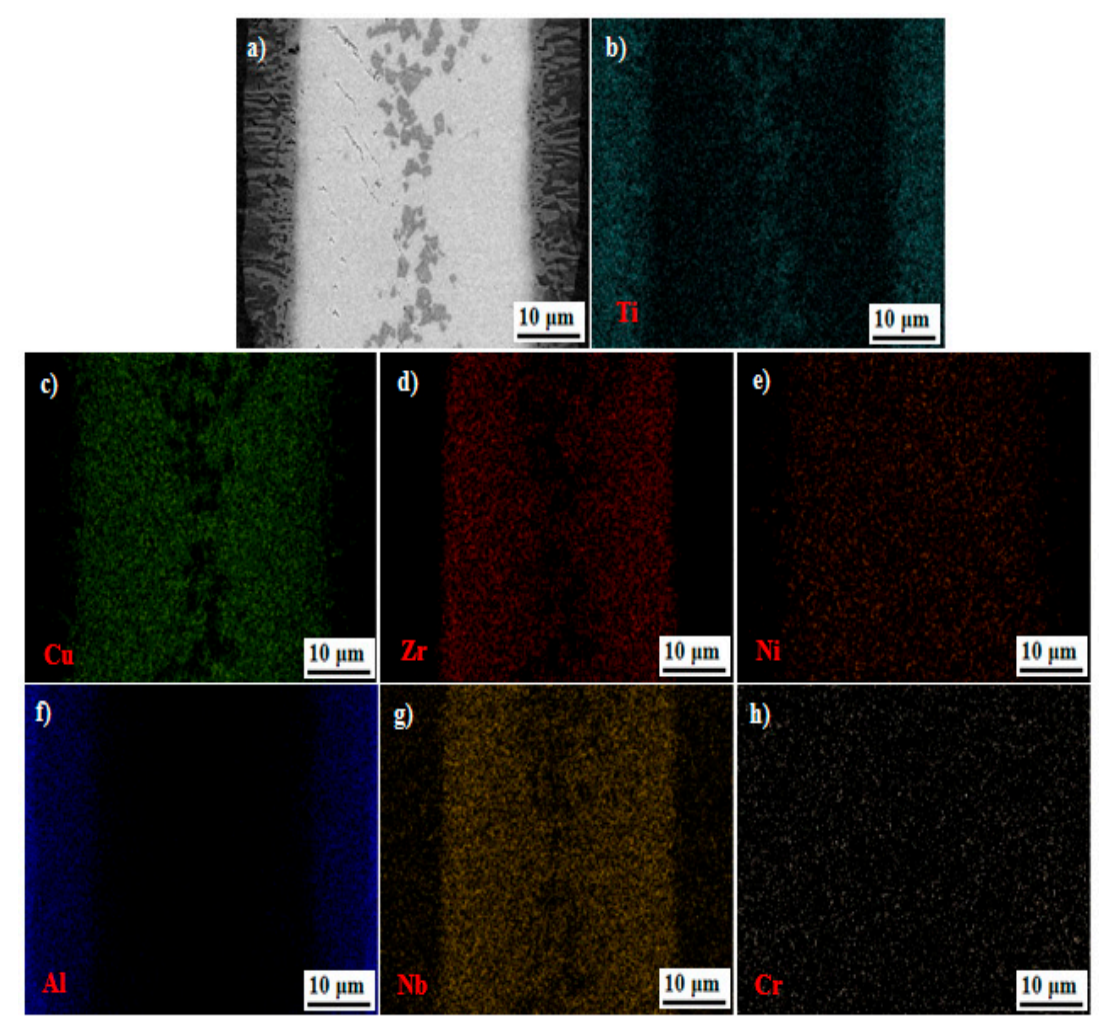

Figure 3. Interfacial microstructure and elemental distribution of Ti-48Al-2Nb-2Cr alloy joint brazed at $1213 \mathrm{~K}$ for 600 s. (a) SEM image and (b) Ti, (c) Cu, (d) Zr, (e) Ni, (f) Al, (g) Nb, (h) Cr. 

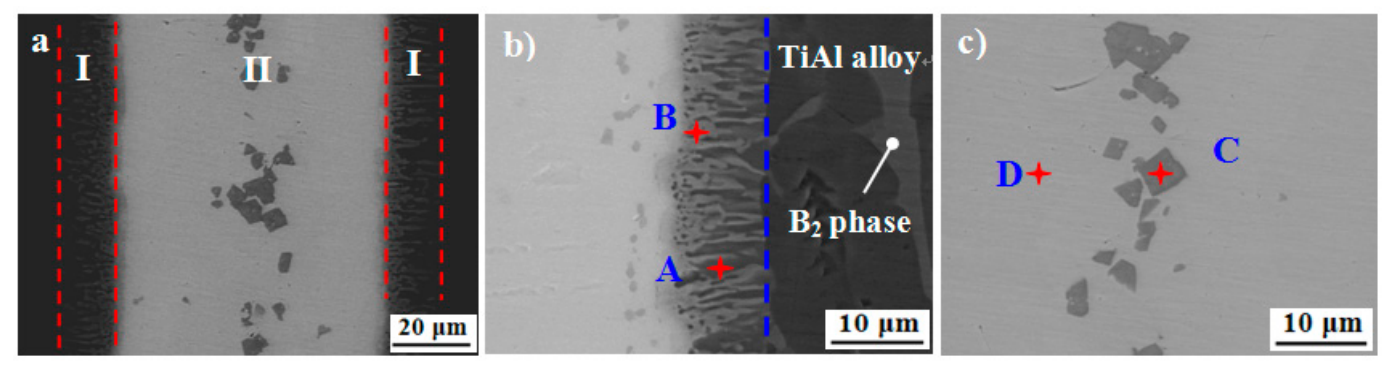

Figure 4. (a) SEM image of the joint interface brazed at $1213 \mathrm{~K}$ for $600 \mathrm{~s}$; (b) magnification image of zone I; (c) magnification image of zone II.

Table 2. Chemical composition and possible phase of each spot marked in Figure 3 (at. \%).

\begin{tabular}{ccccccccc}
\hline Spots & $\mathbf{T i}$ & $\mathbf{A l}$ & $\mathbf{C u}$ & $\mathbf{Z r}$ & $\mathbf{N i}$ & $\mathbf{N b}$ & $\mathbf{C r}$ & Possible Phase \\
\hline $\mathrm{A}$ & 60.05 & 31.21 & 0.50 & 0.44 & 0.03 & 1.51 & 3.27 & $\mathrm{Ti}_{2} \mathrm{Al}$ \\
$\mathrm{B}$ & 28.39 & 30.38 & 28.41 & 6.54 & 6.44 & 1.47 & 3.58 & $\mathrm{AlTiCu}$ \\
$\mathrm{C}$ & 76.94 & 6.83 & 5.00 & 5.11 & 3.49 & 0.56 & 3.08 & $\alpha-\mathrm{Ti}$ \\
$\mathrm{D}$ & 40.03 & 15.90 & 24.06 & 14.41 & 4.59 & 1.63 & 4.49 & $(\mathrm{Ti}, \mathrm{Zr})_{2}(\mathrm{Zr}, \mathrm{Ni})$ \\
\hline
\end{tabular}

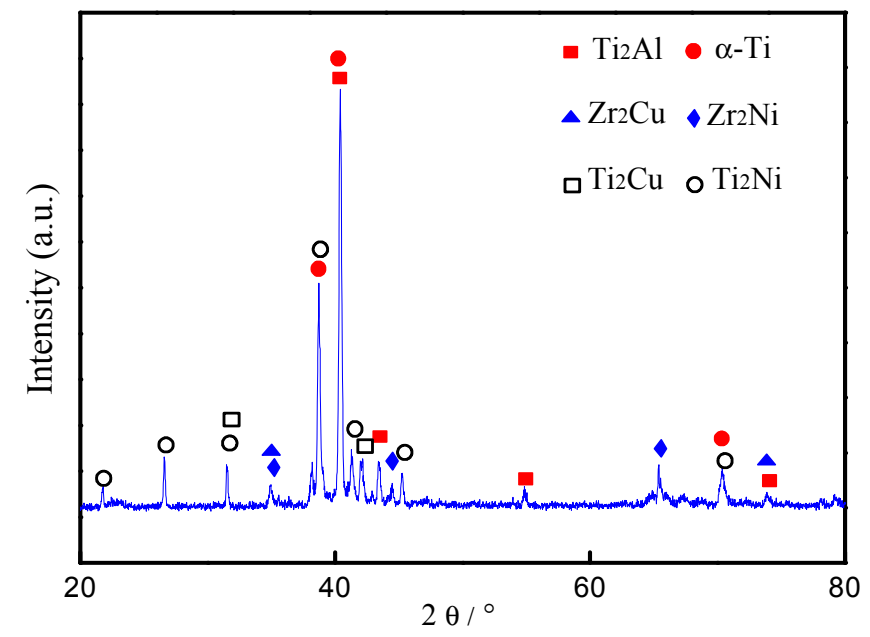

Figure 5. X-ray diffraction (XRD) pattern of fractured surface of brazed joint.

Figure 6 shows the SEM images of the brazed joint at different brazing temperatures for $600 \mathrm{~s}$. Obviously, two characteristic zones can be seen in all of the brazed joints, and a continuous lamellar interface reaction layers forms in the interface, which is the same as in Figure 4a. The width of the whole joint remains unchanged with the brazing temperature. However, the width of the interfacial reaction layer zone I increased with the brazing temperature. Correspondingly, the width of the central brazed layer zone II decreased. For $1123 \mathrm{~K}$, the width of interfacial reaction layer was about $5 \mu \mathrm{m}$. When the brazing temperature reached $1273 \mathrm{~K}$, the width of the interfacial reaction layer increased to $15 \mu \mathrm{m}$. Also, the amount of the black phase in the interfacial reaction layer defined as the $\mathrm{Ti}_{2} \mathrm{Al}$ phase increased. However, compared with the $\mathrm{Ti}_{2} \mathrm{Al}$ phase, the amount of gray phase AlCuTi decreased in the interfacial reaction layer. It is reported that once the continuous TiAl intermetallic compounds form in the joint interface, further atomic interdiffusion between the base material and filler metal will be obstructed due to the limited solubility of $\mathrm{Cu}$ and $\mathrm{Ni}$ in the TiAl alloy [39]. Hence, the existence of $\mathrm{Ti}_{2} \mathrm{Al}$ obstructs the growth of AlCuTi in the interfacial reaction layer. The block-like $\alpha$-Ti grows and accumulates with increasing brazing temperature. 

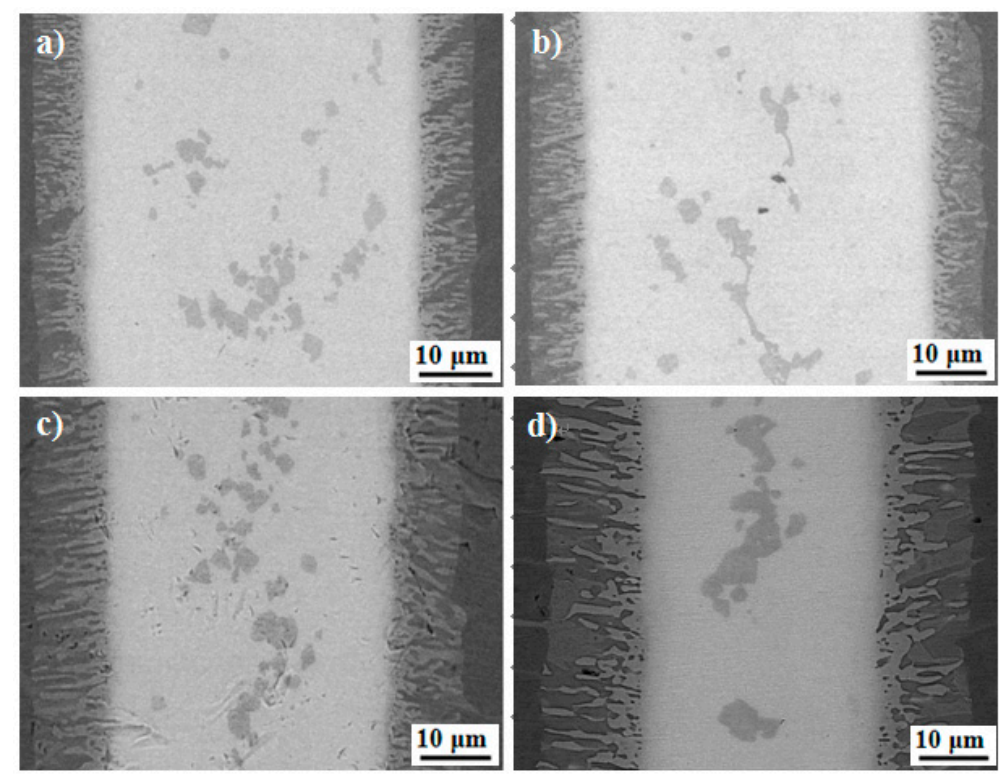

Figure 6. Interfacial microstructures of the joints brazed for $600 \mathrm{~s}$ at brazing temperature of (a) $1183 \mathrm{~K}$; (b) $1213 \mathrm{~K}$; (c) $1243 \mathrm{~K}$; and (d) $1273 \mathrm{~K}$.

From the above experimental results, we propose a possible formation model to explain the microstructure evolution of the joint, as shown in Figure 7. During brazing, when the temperature was brought to the melting point of a Cu-based amorphous alloy filler, the filler began to melt, and wetted the surface of Ti-48Al-2Nb-2Cr base materials. The base materials were partially dissolved into the molten alloy. The $\mathrm{Ti}$ and $\mathrm{Al}$ diffused into the molten filler due to the concentration gradient. At the same time, the elements in the molten filler, especially the $\mathrm{Cu}$, diffused into the Ti-48Al-2Nb-2Cr base materials, as shown in Figure 7a. During the heat process, the Ti and Al contents of the $\gamma$-TiAl and $\alpha_{2}-\mathrm{Ti}_{3} \mathrm{Al}$ phases in the Ti-48Al-2Nb-2Cr base materials gradually decreased, and eventually fell below the critical composition required for their existence [40]. As a consequence, the $\gamma$-TiAl and $\alpha_{2}-\mathrm{Ti}_{3} \mathrm{Al}$ phases transformed into the $\mathrm{Ti}_{2} \mathrm{Al}$ phase through chemical reactions of $\mathrm{TiAl} \rightarrow \mathrm{Al}+\mathrm{Ti}_{2} \mathrm{Al}$ and $\mathrm{Ti}_{3} \mathrm{Al} \rightarrow \mathrm{Ti}+\mathrm{Ti}_{2} \mathrm{Al}$, respectively. Meanwhile, an eutectic reaction occurred based on $\mathrm{Cu}-\mathrm{Ni}-\mathrm{Ti}$ (Zr) ternary phase diagram $L \rightarrow \beta-\mathrm{Ti}+(\mathrm{Ti}, \mathrm{Zr})_{2}(\mathrm{Cu}, \mathrm{Ni})$, as shown in Figure $7 \mathrm{~b}$. With the further interdiffusion at the interface, the AlCuTi phase appeared according to the Al-Cu-Ti ternary alloy phase diagram. When the brazing temperature was further increased, the thickness of the interfacial reaction layers containing $\mathrm{AlCuTi}$ and $\mathrm{Ti}_{2} \mathrm{Al}$ increased. In addition, the $(\mathrm{Ti}, \mathrm{Zr})_{2}(\mathrm{Cu}, \mathrm{Ni})$ phase grew and aggregated, as shown in Figure 7c. At the cooling stage, when the brazing temperature is lower than the $\beta \rightarrow \alpha$ transformation temperature, the eutectoid decomposition of $\beta$-Ti to $\alpha$-Ti and ( $\mathrm{Ti}, \mathrm{Zr})_{2}(\mathrm{Cu}, \mathrm{Ni})$ phases happens: $\beta-\mathrm{Ti} \rightarrow \alpha-\mathrm{Ti}+(\mathrm{Ti}, \mathrm{Zr})_{2}(\mathrm{Cu}, \mathrm{Ni})$. Therefore, the central reaction layer was finally formed with $\alpha$-Ti and $(\mathrm{Ti}, \mathrm{Zr})_{2}(\mathrm{Cu}, \mathrm{Ni})$, as shown in Figure $7 \mathrm{~d}$. 


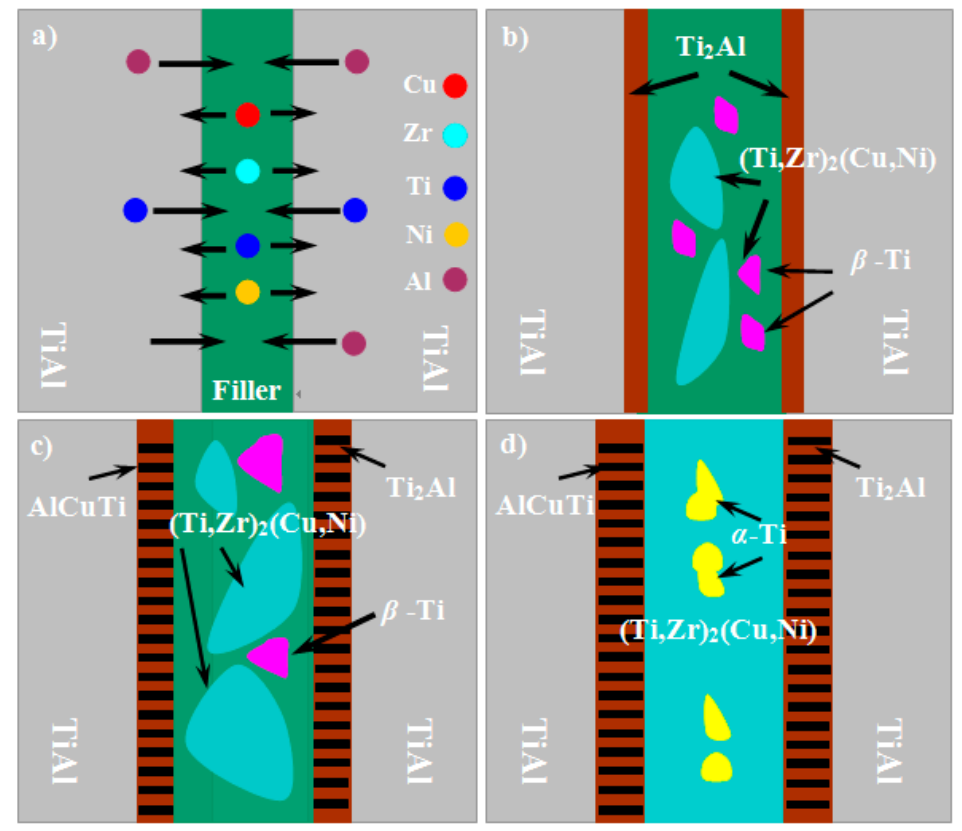

Figure 7. Formation model of joint: (a) dissolution and diffusion of elements; (b) formation of reaction layers; (c) formation of AlCuTi and growth of reaction layers; and (d) formation of $\alpha$-Ti.

\subsection{Mechanical Properties of the Brazed Joint}

Figure 8 shows the room temperature shear strength of the joints brazed at different temperatures for $600 \mathrm{~s}$. It can be seen that the shear strength of the joint is not satisfactory at low brazing temperatures. When brazed at $1183 \mathrm{~K}$, the shear strength is very low: about $160 \mathrm{MPa}$. The main cause is the low amount of atomic diffusion and the insufficient dissolution reaction between the TiAl base alloy and the molten $\mathrm{Cu}$-based filler metal. With the increasing brazing temperature, the joint strength changed correspondingly. When the brazing temperature is up to $1213 \mathrm{~K}$, the maximum strength achieved $266 \mathrm{MPa}$. Two aspects could contribute to the maximum shear strength. Firstly, the increased brazing temperature can improve dissolution and diffusion, leading to the formation of the appropriate interfacial reaction layers in the interface [23,41]. In the present work, the brazing temperature changes the thickness of the reaction layers, as shown in Figure 6, and thus affects the joint strength directly. At the lower brazing temperature, the main cause was the low amount of atomic diffusion and the insufficient dissolution reaction between the TiAl base alloy and the molten Cu-based filler metal, which resulted in lower joint strength. Contrarily, the higher brazing temperature promoted the growth of reaction layers. It is reported that the thickness of the reaction layer dramatically influences the strength of the joint, and there is an optimized thickness of the reaction layers for brazed joints [42]. So, the strength of the reaction layers could be weakened when its thickness exceeds the best value. Secondly, a certain amount of AlCuTi phase homogeneously distributed in the interface, which made the reaction layers a metal matrix reinforced by AlCuTi particles. Further increasing the brazing temperature led to a dramatic deterioration of its bonding strength, and the shear strength was decreased to $197 \mathrm{MPa}$ at $1273 \mathrm{~K}$ for $600 \mathrm{~s}$. It is suggests that residual stresses might be yielded in the brazed joint due to the mismatch of the thermal expansion coefficient and Young's modulus between the TiAl base material and the filler metal during the cooling process. These residual stresses can induce microcracks in the interface and deteriorate the mechanical properties [43]. Moreover, further increasing the brazing temperature leads to a larger amount and size of brittle intermetallics (e.g., $\mathrm{Ti}_{2} \mathrm{Al}$ and $\mathrm{AlCuTi}$ ) at the interface, as shown in Figure 6. The existence of these intermetallics weakens the plastic deformation of the joint, which is detrimental to the relaxation of the residual stress in the joint. This consequentially leads to the decrease of shear strength. 


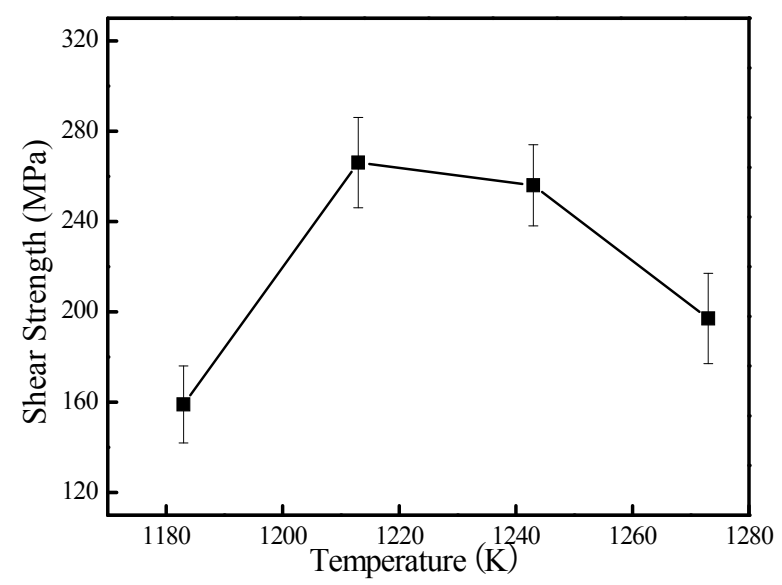

Figure 8. Effect of brazing temperature on shear strength of the joints brazed at different temperature for $600 \mathrm{~s}$.

\section{Conclusions}

The Ti-48Al-2Nb-2Cr alloy has been successfully joined to itself using $\mathrm{Cu}_{41.83} \mathrm{Ti}_{30.21} \mathrm{Zr}_{19.76} \mathrm{Ni}_{8.19}$ (at. \%) amorphous alloy filler. Sound joints can be obtained for 10 min with different temperatures. The typical brazed joint consists of two zones: the interfacial reaction layer and the central reaction layer. The reaction products of $\mathrm{Ti}_{2} \mathrm{Al}, \mathrm{AlCuTi}, \alpha-\mathrm{Ti}$, and $(\mathrm{Ti}, \mathrm{Zr})_{2}(\mathrm{Cu}, \mathrm{Ni})$ were identified in the brazed joint. The size and morphology of the two zones, especially the phase in the interfacial reaction layer, are highly affected by the brazing temperature. It was found that the shear strength changes with the brazing temperature. An optimum shear strength of $266 \mathrm{MPa}$ is achieved under the conditions of $1213 \mathrm{~K}$ for $600 \mathrm{~s}$. The successful preparation of high strength Ti-48Al-2Nb-2Cr alloy joints, as well as the proposed formation mechanism, offers a promising brazing route for the fabrication and functionalization of other TiAl intermetallics.

Author Contributions: P.W., W.W. and D.Z. conceived and designed the experiments. G.W., X.S. and W.C. wrote the article. C.T. and Y.S. gave the suggestion of experiments, and provided the materials.

Acknowledgments: This work was supported by the National Natural Science Foundation of China [grant numbers 51704001 and 51501100], Key Project of Natural Science of Education Department of Anhui Province [grant numbers KJ2018A0860 and KJ2016A060], Talent Project of Anhui Province [grant number gxyqZD2016126] and the Open Fund of State Key Laboratory of Advanced Welding and Joining [grant number AWJ-16-M04]. W. Cao acknowledges financial supports from the profile funding of the Academy of Finland.

Conflicts of Interest: The authors declare no conflict of interest.

\section{References}

1. Dimiduk, D.M. Gamma titanium aluminide alloys-An assessment within the competition of aerospace structural materials. Mater. Sci. Eng. A 1999, 263, 281-288. [CrossRef]

2. $\mathrm{Wu}, \mathrm{X} . \mathrm{H}$. Review of alloy and process development of TiAl alloys. Intermetallics 2006, 14, 1114-1122. [CrossRef]

3. Zghal, S.; Thomas, M.; Naka, S.; Finel, A.; Couret, A. Phase transformations in TiAl based alloys. Acta Mater. 2005, 53, 2653-2664. [CrossRef]

4. Garip, Y.; Ozdemir, O. Hot corrosion behavior of Ti-48Al and Ti-48Al-2Cr intermetallic alloys produced by electric current activated sintering. Metall. Mater. Trans. A 2018, 49, 2455-2462. [CrossRef]

5. Liu, Y.Y.; Yao, Z.K.; Guo, H.Z.; Yang, H.H. Microstructure and property of the Ti-24Al-15Nb-1.5Mo/TC11 joint welded by electron beam welding. Int. J. Miner. Metall. Mater. 2009, 16, 568-575. [CrossRef]

6. Basile, G.; Baudana, G.; Marchese, G.; Lorusso, M.; Lombardi, M.; Ugues, D.; Fino, P.; Biamino, S. Characterization of an additive manufactured TiAl alloy-steel joint produced by electron beam welding. Materials 2018, 11, E149. [CrossRef] [PubMed] 
7. Lei, Z.L.; Dong, Z.J.; Chen, Y.B.; Huang, L.; Zhu, R.C. Microstructure and mechanical properties of laser welded Ti-22Al-27Nb/TC4 dissimilar alloys. Mater. Sci. Eng. A 2013, 559, 909-916. [CrossRef]

8. Du, Z.H.; Zhang, K.F.; Lu, Z.; Jiang, S.S. Microstructure and mechanical properties of vacuum diffusion bonding joints for $\gamma$-TiAl based alloy. Vacuum 2018, 150, 96-104. [CrossRef]

9. Simões, S.; Viana, F.; Kocak, M.; Ramos, A.S.; Vieira, M.T.; Vieira, M.F. Diffusion bonding of TiAl using reactive Ni/Al nanolayers and Ti and Ni foils. Mater. Chem. Phys. 2011, 128, 202-207. [CrossRef]

10. Simoes, S.; Ramos, A.S.; Viana, F.; Vieira, M.T.; Vieira, M.F. Joining of TiAl to steel by diffusion bonding with $\mathrm{Ni} / \mathrm{Ti}$ reactive multilayers. Metals 2016, 6, 96. [CrossRef]

11. Lee, S.J.; $\mathrm{Wu}, \mathrm{S} . \mathrm{K}$. Infrared joining strength and interfacial microstructures of Ti-48Al-2Nb-2Cr intermetallics using Ti-15Cu-15Ni foil. Intermetallics 1999, 7, 11-21. [CrossRef]

12. Wang, Y.; Cai, X.Q.; Yang, Z.W.; Qiu, Q.W.; Wang, D.P.; Liu, Y.C. Microstructure evolution and mechanical properties of Ti-22Al-25Nb alloy joints brazed with Ti-Ni-Nb alloy. Mater. Chem. Phys. 2016, 182, 488-497. [CrossRef]

13. Shiue, R.K.; Wu, S.K.; Chen, Y.T.; Shiue, C.Y. Infrared brazing of $\mathrm{Ti}_{50} \mathrm{Al}_{50}$ and Ti-6Al-4V using two Ti-based filler metals. Intermetallics 2008, 16, 1083-1089. [CrossRef]

14. Liu, X.P.; Zhang, L.X.; Sun, Z.; Feng, J.C. Microstructure and mechanical properties of transparent alumina and TiAl alloy joints brazed using Ag-Cu-Ti filler metal. Vacuum 2018, 151, 80-89. [CrossRef]

15. Dai, X.Y.; Cao, J.; Liu, J.K.; Su, S.; Feng, J.C. Effect of holding time on microstructure and mechanical properties of $\mathrm{ZrO} 2 / \mathrm{TiAl}$ joints brazed by $\mathrm{Ag}-\mathrm{Cu}$ filler metal. Mater. Des. 2015, 87, 53-59. [CrossRef]

16. Shiuea, R.K.; Wu, S.K.; Chen, S.Y. Infrared brazing of TiAl using Al-based braze alloys. Intermetallics 2003, 11, 661-671. [CrossRef]

17. Song, X.G.; Ben, B.Y.; Hu, S.P.; Feng, J.C.; Tang, D.Y. Vacuum brazing high Nb-containing TiAl alloy to Ti60 alloy using Ti-28Ni eutectic brazing alloy. J. Alloys Compd. 2017, 692, 485-491. [CrossRef]

18. Cao, J.; Dai, X.Y.; Liu, J.Q.; Si, X.Q.; Feng, J.C. Relationship between microstructure and mechanical properties of TiAl/Ti2AlNb joint brazed using Ti-27Co eutectic filler metal. Mater. Des. 2017, 121, 176-184. [CrossRef]

19. Song, X.G.; Cao, J.; Chen, H.Y.; Wang, Y.F.; Feng, J.C. Brazing TiAl intermetallics using TiNi-V eutectic brazing alloy. Mater. Sci. Eng. A 2012, 551, 133-139. [CrossRef]

20. Wang, G.; Xiao, P.; Huang, Z.J.; He, R.J. Brazing of $\mathrm{ZrB}_{2}-\mathrm{SiC}$ ceramic with amorphous CuTiNiZr filler. Ceram. Int. 2016, 42, 5130-5135. [CrossRef]

21. Liu, Y.H.; Hu, J.D.; Shen, P.; Han, X.H.; Li, J.C. Microstructural and mechanical properties of jointed $\mathrm{ZrO}_{2} / \mathrm{Ti}-6 \mathrm{Al}-4 \mathrm{~V}$ alloy using $\mathrm{Ti}_{33} \mathrm{Zr}_{17} \mathrm{Cu}_{50}$ amorphous brazing filler. Mater. Des. 2013, 47, 281-286. [CrossRef]

22. Lee, M.K.; Lee, J.G. Mechanical and corrosion properties of Ti-6Al-4V alloy joints brazed with a low-melting-point 62.7Zr-11.0Ti-13.2Cu-9.8Ni-3.3Be amorphous filler metal. Mater. Charact. 2013, 81, $19-27$. [CrossRef]

23. Li, X.Q.; Li, L.; Hu, K.; Qu, S.G. Vacuum brazing of TiAl-based intermetallics with Ti-Zr-Cu-Ni-Co amorphous alloy as filler metal. Intermetallics 2015, 57, 7-16. [CrossRef]

24. Wang, Y.; Jiao, M.; Yang, Z.W.; Wang, D.P.; Liu, Y.C. Vacuum brazing of Ti2AlNb and TC4 alloys using $\mathrm{Ti}-\mathrm{Zr}-\mathrm{Cu}-\mathrm{Ni}$ and $\mathrm{Ti}-\mathrm{Zr}-\mathrm{Cu}-\mathrm{Ni}+\mathrm{Mo}$ filler metals: Microstructural evolution and mechanical properties. Arch. Civ. Mech. Eng. 2018, 18, 546-556. [CrossRef]

25. Cai, Y.S.; Liu, R.C.; Zhu, Z.W.; Cui, Y.Y.; Yang, R. Effect of brazing temperature and brazing time on the microstructure and tensile strength of TiAl-based alloy joints with Ti-Zr-Cu-Ni amorphous alloy as filler metal. Intermetallics 2017, 91, 35-44. [CrossRef]

26. Lu, Z.P.; Shen, J.; Xing, D.W.; Sun, J.F.; Liu, C.T. Binary eutectic clusters and glass formation in ideal glass-forming liquids. Appl. Phys. Lett. 2006, 89, 071910. [CrossRef]

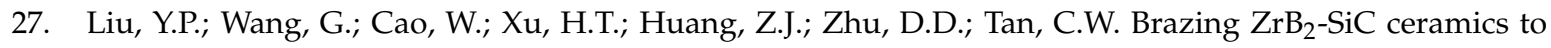
Ti6Al4V alloy with TiCu-based amorphous filler. J. Manuf. Process. 2017, 30, 516-522. [CrossRef]

28. Liu, Y.; Hu, R.; Zhang, T.B.; Kou, H.C.; Wang, J.; Yang, G.; Li, J.S. Dendritic growth and microstructure evolution with different cooling rates in Ti48Al2Cr2Nb alloy. J. Mater. Eng. Perform. 2016, 25, 38-45. [CrossRef]

29. Liu, Y.; Hu, R.; Kou, H.C.; Zhang, T.B.; Wang, J.; Li, J.S. A mixture of massive and feathery microstructures of Ti48Al2Cr2Nb alloy by high undercooled solidification. Mater. Charact. 2015, 100, 104-107. [CrossRef]

30. Niu, H.Z.; Chen, Y.Y.; Xiao, S.L.; Xu, L.J. Microstructure evolution and mechanical properties of a novel beta g-TiAl alloy. Intermetallics 2012, 31, 225-231. [CrossRef] 
31. Ren, H.S.; Xiong, H.P.; Chen, B.; Pang, S.J.; Chen, B.Q.; Ye, L. Vacuum brazing of Ti3Al-based alloy to TiAl using TiZrCuNi(Co) fillers. J. Mater. Process. Technol. 2015, 224, 26-32. [CrossRef]

32. Yang, S.J.; Nam, S.W. Investigation of $\alpha_{2} / \gamma$ phase transformation mechanism under the interaction of dislocation with lamellar interface in primary creep of lamellar TiAl alloys. Mater. Sci. Eng. A 2002, 329-331, 898-905. [CrossRef]

33. Cao, G.H.; Skrotzki, W.; Gemming, T. Transmission electron microscopy investigation of $\mathrm{Ti}_{2} \mathrm{Al}$ precipitation in titanium aluminides during high-strain torsion. J. Alloys Compd. 2006, 417, 169-172. [CrossRef]

34. Xiong, H.P.; Shen, Q.; Li, J.G.; Zhang, L.M. Design and microstructures of Ti/TiAl/Al system functionally graded material. J. Mater. Sci. Lett. 2000, 19, 989-993. [CrossRef]

35. Shiue, R.K.; Wu, S.K.; Chen, S.Y. Infrared brazing of TiAl intermetallic using BAg-8 braze alloy. Acta Mater. 2003, 51, 1991-2004. [CrossRef]

36. Qiu, Q.W.; Wang, Y.; Yang, Z.W.; Hu, X.; Wang, D.P. Microstructure and mechanical properties of TiAl alloy joints vacuum brazed with Ti-Zr-Ni-Cu brazing powder without and with Mo additive. Mater. Des. 2016, 90, 650-659. [CrossRef]

37. Li, L.; Li, X.Q.; Hu, K.; Qu, S.G.; Yang, C.; Li, Z.F. Effects of brazing temperature and testing temperature on the microstructure and shear strength of $\gamma$-TiAl joints. Mater. Sci. Eng. A 2015, 634, 91-98. [CrossRef]

38. Lee, J.G.; Choi, Y.H.; Lee, J.K.; Lee, G.J.; Lee, M.K.; Rhee, C.K. Low-temperature brazing of titaniumby the application of a Zr-Ti-Ni-Cu-Be bulk metallic glass (BMG) alloyas a filler. Intermetallics 2010, 18, 70-73. [CrossRef]

39. Shiue, R.K.; Wu, S.K.; Chen, Y.T. Strong bonding of infrared brazed $\alpha_{2}-\mathrm{Ti}_{3} \mathrm{Al}$ and Ti-6Al-4V using Ti-Cu-Ni fillers. Intermetallics 2010, 18, 107-114. [CrossRef]

40. Herrmann, D.; Appel, F. Diffusion bonding of $\gamma$ (TiAl) alloys: Influence of composition, microstructure, and mechanical properties. Metall. Mater. Trans. A 2009, 40, 1881-1902. [CrossRef]

41. Hong, I.T.; Koo, C.H. Microstructural evolution and shear strength of brazing C103 and Ti-6Al-4V using Ti-20Cu-20Ni-20Zr (wt \%) filler metal. Int. J. Refract. Met. Hard Mater. 2006, 24, 247-252. [CrossRef]

42. Wang, G.; Huang, Y.J.; Wang, G.C.; Shen, J.; Chen, Z.H. Brazing of $\mathrm{Ti}_{2} \mathrm{AlNb}$ based alloy with amorphous Ti-Cu-Zr-Ni filler. J. Wuhan Univ. Technol. 2015, 30, 617-621. [CrossRef]

43. Tian, X.Y.; Feng, J.C.; Shi, J.M.; Li, H.W.; Zhan, L.X. Brazing of ZrB 2 -SiC-C ceramic and GH99 superalloy to form reticular seam with low residual stress. Ceram. Int. 2015, 41, 145-153. [CrossRef] 